\title{
COMPARATIVE CALORIGENIC ACTION OF NORMAL AND PATHO- LOGICAL THYROID GLANDS ADMINISTERED IN EQUI-THYROXINE DOSES
}

\author{
By W. W. PALMER AND J. P. LELAND \\ (From the Department of Medicine, College of Physicians and Surgeons, Columbia University, \\ and the Presbyterian Hospital, New York City)
}

(Received for publication May 20, 1935)

The purpose of this communication is to present evidence concerning two important questions of thyroid physiology.

1. Is the calorigenic activity of the thyroid gland proportional to its thyroxine content as determined chemically or to its total iodine?

2. Is the toxicity observed in Graves' disease caused entirely by an excessive secretion of normal thyroid hormone or is it due wholly or in part to the elaboration of an abnormal substance more toxic than the normal hormone?

In reference to the first question, the rôle of thyroxine in relation to the activity of the thyroid gland, there is disagreement among the several workers in the field. Hunt and Seidell (1), using a method in which the minimum lethal dose of acetonitrile for thyroid treated mice is determined and compared with that for untreated control mice, found a constant parallelism between the activity and the total iodine content of the thyroid preparations tested. Krogh and Lindberg (2) found that the increase in oxygen consumption of guinea pigs was proportional to the total iodine of dried thyroid gland when they used normal hog thyroids and the thyroid glands of patients with simple goiter or with exophthalmic goiter successfully treated with iodine. When, however, glands from exophthalmic goiter patients who were not treated with iodine or who failed to respond to treatment were used, the biological activity per milligram of total iodine was less than that of normal glands. Means, Lerman and Salter (3), using preparations analyzed for thyroxine by the method of Harington and Randall (4), have concluded from work with myxedema patients that the activity of desiccated thyroid gland is proportional to its total iodine content. Working also with myxedema patients, Thompson, McClellan, Thompson and Dickie (5) reported similar results in their earlier work but more recently (6) have obtained figures that lead them to doubt their first conclusions and to consider that the question remains unanswered.

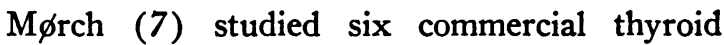
preparations by measuring the carbon dioxide output of mice before and after dosage but failed to find a parallelism between the total iodine content and the effect on metabolism. The same conclusion was reached by Kreitmair (8) who followed the loss in weight of guinea pigs after the administration of the glands.

Gaddum and Hetherington (9), using M $\varnothing r c h$ 's method, found only a rough proportionality between the calorigenic activity of a series of thyroid gland preparations and their thyroxine content, estimated according to the method of Harington and Randall. On the other hand, Rotter and Mecz (10) and also Sjögren and Lundgren (11) obtained a fairly uniform proportionality between thyroxine content and potency as measured by the loss of weight in guinea pigs by the method of Freud and Nobel (12) and Kreitmair (8) obtained a fairly uniform proportionality between the calorigenic effect and the thyroxine content.

To obtain evidence with reference to these questions it was decided to make comparisons between the calorigenic activity of a commercial thyroid preparation, used as a standard, and desiccated thyroid preparations in which the ratios of thyroxine iodine to total iodine varied widely from the standard. With such a series of preparations it should be apparent whether the activity is parallel to the total iodine or to the thyroxine iodine content. It has been shown previously in this laboratory that pathological glands may be found with widely varying ratios of thyroxine iodine to total iodine.

\section{METHOD}

The preparations studied were: (1) a commercial thyroid powder of Burroughs Wellcome 
Co. (the "standard"), (2) nine human thyroids (both normal and pathological), (3) another commercial preparation, (4) a specimen of hog thyroglobulin, and (5) pure crystalline thyroxine. The thyroid preparations were analyzed for total iodine by a modification of Kendall's method (13) and for thyroxine by the method of Leland and Foster (14). It is believed for reasons previously given (14) that the figures obtained by the method of Leland and Foster more closely approach the true thyroxine values than do those by the method of Harington and Randall (4) which gives much higher results.

Since it was considered advisable to study individual human thyroid glands the available material for experimentation was limited and it became necessary, therefore, to use small animals. The method devised by $M \phi r c h$ in which the test animals used are mice was attempted but in our hands (15) proved unsatisfactory. A change was made, therefore, to the procedure recommended by Krogh and Lindberg (2), that of determining the oxygen consumption of guinea pigs. In the main the experimental details suggested by these workers were adhered to closely. Minor changes made in the method will be described together with details of diet not mentioned by Krogh and Lindberg.

Male guinea pigs, from 600 to 800 grams in weight, obtained from the same stock throughout the investigation, were fed a dry diet consisting of two parts by weight of crushed oats to one part of bran supplemented by carrots and 80 grams of lettuce daily. The animals were transferred to starvation cages from 12 to 14 hours before the metabolism was determined. In spite of the long daily starvation period, the animals maintained their weight or gained on the diet except in two or three instances. In those cases where a steady weight loss was noted during the preliminary period the animals were discarded.

After an interval of several days during which the animals became adjusted to the experimental conditions, the normal resting metabolism (consumption of oxygen) was determined daily, including Sunday, over a period of six to ten days before thyroid administration was begun. Since some animals showed considerable variation in their $\mathrm{O}_{2}$ consumption from day to day, this relatively long period was considered necessary to obtain a fair average normal. A mean for each animal was calculated from all of the values found over this period. The average deviation of the individual values from their mean was 3.4 per cent.
Immediately following the determination of the normal, thyroid administration was begun and was continued over a fourteen day period. Every other day the animal was given by mouth a dose of a watery suspension of gland material. No difficulty was encountered in giving the dose as preliminary training in drinking from a pipette had been accomplished during the period of adjustment. Throughout the experimental period the metabolism was determined daily. A 150 cc. spirometer was used and the oxygen consumption recorded on Benedict-Roth kymograph sheets of the type used with their portable apparatus. These sheets also served as a record of the activity of the animal, for any movement within the metabolism chamber changed the pressure and caused a rise and fall of the needle on the graph. Instead of using a pump, the respiration chamber was aerated by means of a rocking device (16) containing 40 per cent potassium hydroxide for the absorption of carbon dioxide. Analysis of the air in the system showed that the carbon dioxide was promptly absorbed. The determinations themselves covered a period of one hour instead of 30 minutes. The first 15 minute period during which the temperature throughout the system was becoming constant was discarded. Three ten minute periods were then obtained; if all three or two of these three periods agreed within 5 per cent, the results were accepted and averaged.

All results are expressed in oxygen consumption per square meter of surface area per minute using Meeh's formula for surface area, $S=k \sqrt[3]{w^{2}}$ ( $w=$ weight in kgm.), with Rubner's factor, $k=.085$, for guinea pigs. The average normal resting metabolism of 116 male guinea pigs was found to be $97 \mathrm{cc}$. oxygen per square meter per minute with a dispersion of \pm 13 and a standard deviation $\left(\sigma=\sqrt{\Sigma x^{2} / N}\right)$ of 5.3. The percentage increase in oxygen consumption following administration of thyroid was computed on the basis of the individual animal's normal average and not on the group normal average as was done by Krogh and Lindberg.

\section{EXPERIMENTAL}

In order to establish the relation between size of dose and magnitude of response, the standard preparation, Burroughs Wellcome, was given in amounts containing 4.50, 2.25, 1.69, 1.13 and $0.56 \mathrm{mgm}$. of total iodine per square meter of surface. The corresponding thyroxine iodine contents of the standard at these levels of dosage were $1.05,0.52,0.39,0.26$, and $0.13 \mathrm{mgm}$. In Figure 1 a complete picture is given of the increases in oxygen consumption observed over the entire 14 day period at each of the different levels of dosage. The curves are composite curves obtained by averaging each day the oxygen absorption of all of the individual animals of the group receiving the dose. From the lowest curve $(0.13$ 


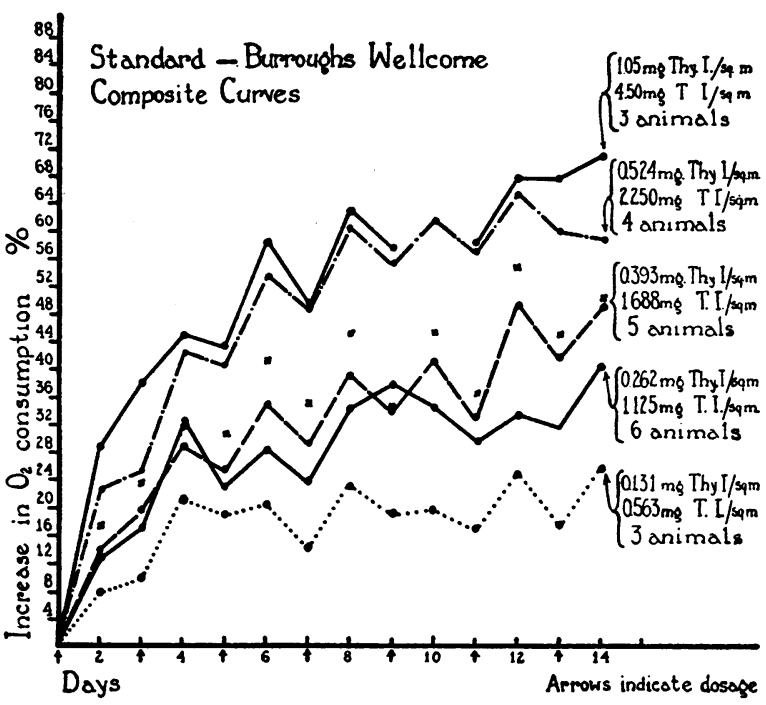

Fig. 1. Composite Curves Obtained by Averaging Daily the Oxygen Consumption of All of the AnImals of Each Group Receiving the Standard Preparation, Burroughs Wellcome Company Thyrotd.

Gland was administered every other day for 14 days at five different levels of dosage. Crosses indicate values obtained in Curve 3 when two unsatisfactory animals were omitted from the group.

mgm. thyroxine iodine) to the next above ( 0.26 mgm. thyroxine iodine) a definite increase in oxygen absorption is observed over the entire period. The third curve ( $0.39 \mathrm{mgm}$. thyroxine iodine) is not significantly higher than the second curve (0.26 mgm. thyroxine iodine) until the end of the dosage period is reached. This is due to the inclusion in the series of the low results obtained on two animals that could not be kept awake until toward the end of the experiment. The crosses indicate the position of the curve when these animals were excluded from the series. The last three days of the experimental period were not complicated by this factor. Although the dose of thyroxine iodine given to the animals of the fifth curve (1.05 mgm. thyroxine iodine) was twice that of the fourth curve $(0.52 \mathrm{mgm}$. thyroxine iodine) the oxygen consumption was only a little greater showing that the amount given was outside the range of sensitivity. At this high level of dosage the increase in oxygen consumption is no longer proportional to the dose administered. The total iodine content of the dose at this level was $4.5 \mathrm{mgm}$. per square meter of surface, the amount chosen by Krogh and Lindberg as their standard dose.

Following the procedure of Krogh and Lindberg, a value was obtained by averaging the increases in oxygen consumption observed on the twelfth, thirteenth, and fourteenth days of the experimental period which was regarded as the full effect of the dose administered. When the standard preparation was given in amounts containing $2.25,1.69,1.13$ and $0.56 \mathrm{mgm}$. of total iodine per square meter of surface, a linear relationship between the increases in oxygen consumption is observed as may be seen by referring to Figure 2. The mean increases in oxygen consumption obtained at the four points which locate the line are respectively $61,47,35$ and 22 per cent. The amount of thyroxine iodine given at each of these levels was $0.52,0.39,0.26$ and 0.13 mgm. per square meter. Within this range of dosage, therefore, a difference of $0.13 \mathrm{mgm}$. thyroxine iodine given results in an appreciable difference in oxygen consumption. Beyond the highest point shown in Figure 2 the curve flattens

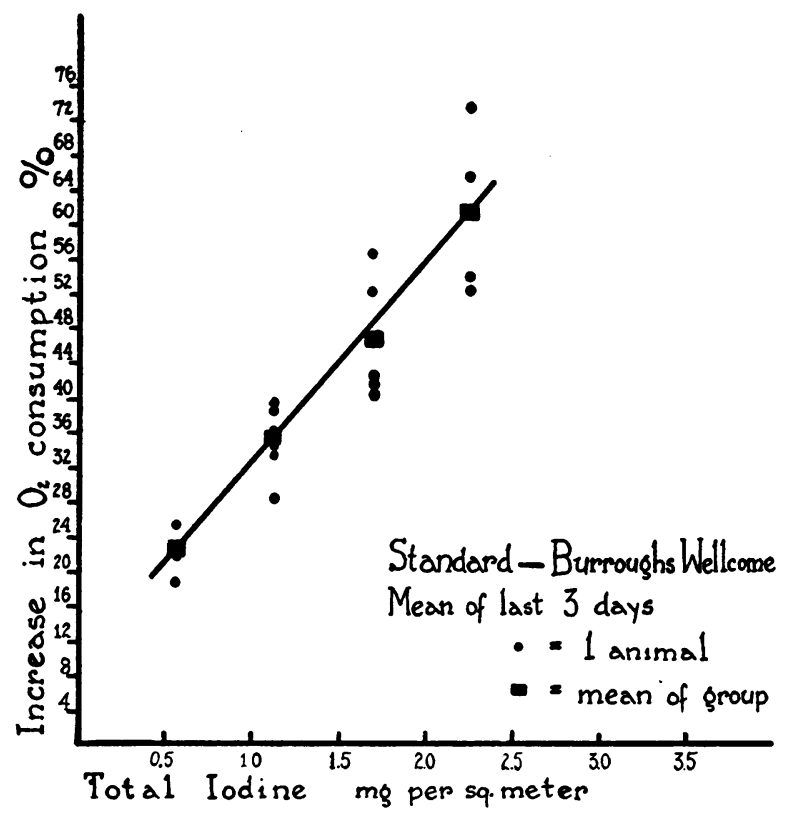

Fig. 2. Curve Showing the Increase in Oxygen Consumption of Guinea Pigs Receiving the Standard Preparation, Burroughs Wellcome Company Thyroid, at Four Different Levels of Dosage.

Each solid dot represents the mean oxygen consumption on the 12th, 13th, and 14th days of the dosage period. 
out, since an increase of only 68 per cent results when $1.05 \mathrm{mgm}$. thyroxine iodine $(4.5 \mathrm{mgm}$. total iodine) per square meter is administered. Krogh and Lindberg used $4.5 \mathrm{mgm}$. of total iodine as their standard dose but obtained an increase in oxygen consumption of only 30 per cent as compared with our increase of 68 per cent at that level. The difference in activity between our standard preparation and the one employed by Krogh and Lindberg is probably explained by a difference in thyroxine content. Since toxic symptoms were observed with thyroid doses producing increases in oxygen consumption of 61 and 47 per cent it was decided to use, when sufficient gland was available, the 35 per cent level of dosage with which to make comparisons of preparations to be studied.

The accompanying weight losses observed with the various dosages of the standard preparation are shown in Table I. As there is only a rough correlation between weight loss and thyroid dosage, the determination of the oxygen consumption is the more delicate method of estimating biological activity.

Having established the mean increase in oxy-
TABLE I

Weight losses accompanying different levels of dosage of Burroughs Wellcome thyroid

\begin{tabular}{|c|c|c|c|}
\hline \multicolumn{2}{|c|}{ Dosage per square meter } & \multirow{2}{*}{$\begin{array}{l}\text { Average increase } \\
\text { in oxygen } \\
\text { consumption }\end{array}$} & \multirow{2}{*}{$\begin{array}{l}\text { Average weight } \\
\text { loss on 14th day }\end{array}$} \\
\hline $\begin{array}{c}\text { Total } \\
\text { iodine }\end{array}$ & $\begin{array}{c}\text { Thyroxine } \\
\text { iodine }\end{array}$ & & \\
\hline mgm. & $m g m$. & per cent & $\begin{array}{l}\text { per cent of average } \\
\text { initial body weight }\end{array}$ \\
\hline $\begin{array}{l}0.56 \\
1.13 \\
1.69 \\
2.25 \\
4.50\end{array}$ & $\begin{array}{l}0.13 \\
0.26 \\
0.39 \\
0.52 \\
1.05\end{array}$ & $\begin{array}{l}22 \\
35 \\
47 \\
61 \\
68\end{array}$ & $\begin{array}{r}6.6 \\
6.6 \\
12.8 \\
13.3 \\
22.3\end{array}$ \\
\hline
\end{tabular}

gen consumption produced by administration of standard normal thyroid in dosages indicated above, the next step was to compare the calorigenic effect of the standard with that of other thyroid preparations in equi-thyroxine iodine dosage. Twelve preparations were compared in equithyroxine doses with the standard. These consisted of nine human thyroid glands (both normal and pathological), a commercial thyroid preparation, hog thyroglobulin and pure crystalline thyroxine. In Table II may be found the chemical analyses and types of glands employed. All anal-

TABLE II

Iodine partition of thyroid gland preparations

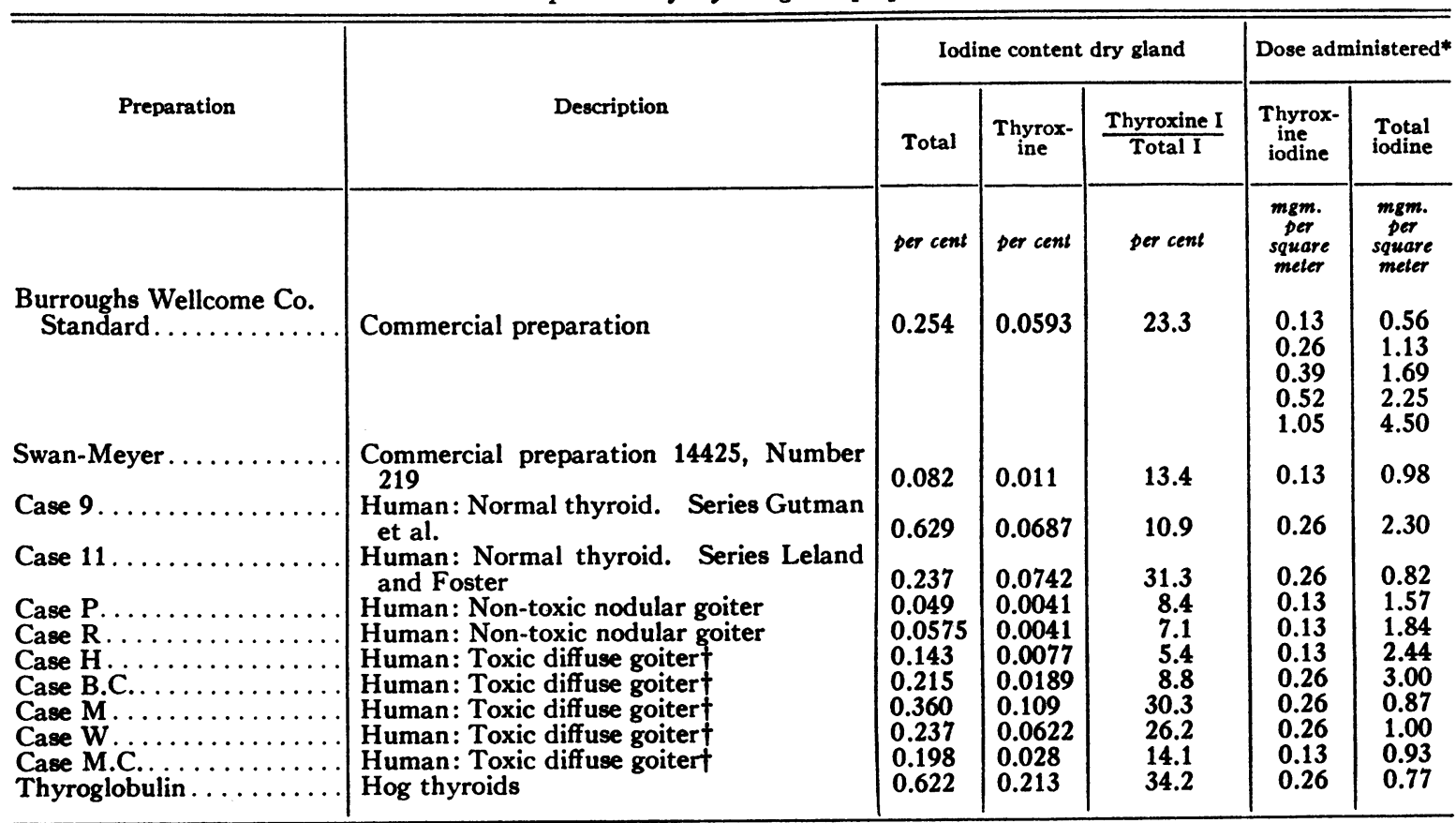

* Dose administered every other day for 14 days.

† Patient received iodine before operation. 
yses for total iodine and thyroxine iodine were made by Dr. G. L. Foster to whom we are greatly indebted. As the thyroxine per cent of total iodine is low the best glands for comparison with the standard are Cases 9, P, R, H and B.C. The total iodine contents of these preparations are respectively $2,2.8,3.3,4.3$ and 2.7 times as great as in an equi-thyroxine dose of the standard.

\section{RESULTS}

The experimental results obtained over the entire fourteen day period of dosage are shown in Figures 3 to 14, and the results found by averaging the oxygen consumption on the 12th, 13th and 14th days are given in Table III.

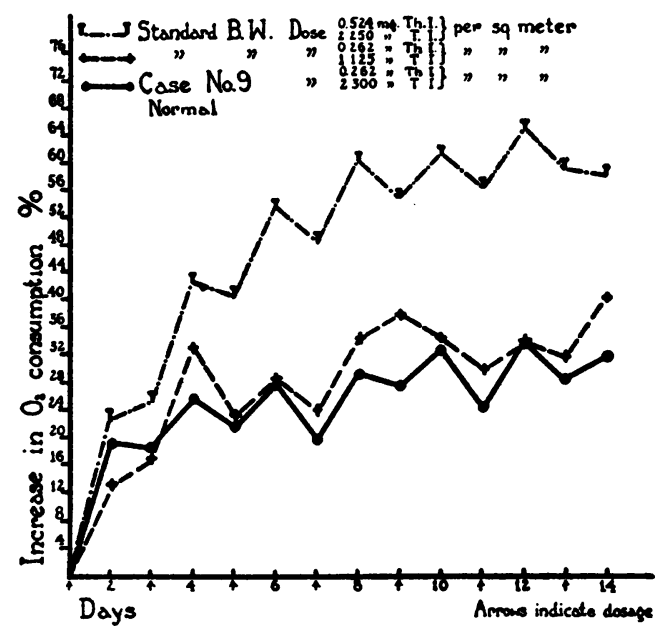

Fic. 3.

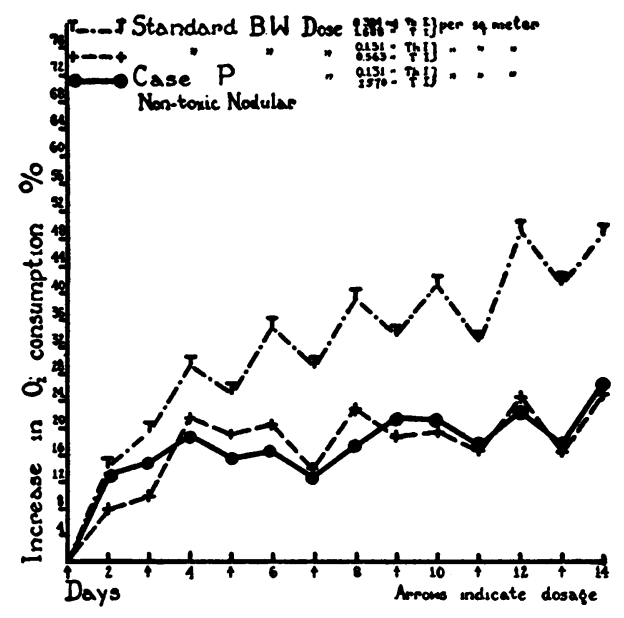

FIG. 5.
Figures 3 to 14 show composite curves obtained by averaging the animals of each group. In each figure the preparation to be compared with the standard is shown together with two Burroughs Wellcome curves, one the exact thyroxine iodine equivalent and the other the nearest total iodine equivalent taken from Figure 2. In the cases where none of the standard curves represented an approximate total iodine equivalent, the curves above and below the theoretical are shown. In these curves the increase in oxygen consumption obtained with the thyroid preparation investigated would approximate that obtained with an equi-thyroxine iodine dosage of the standard if the calorigenic effect were proportional to the

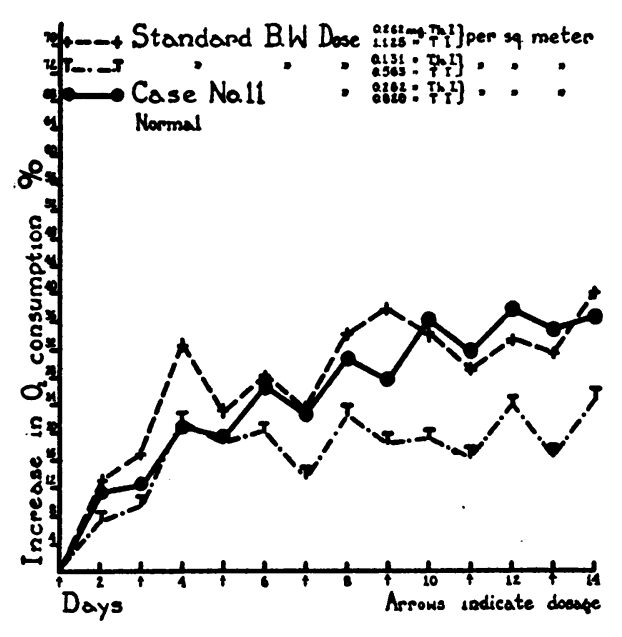

FIG. 4.

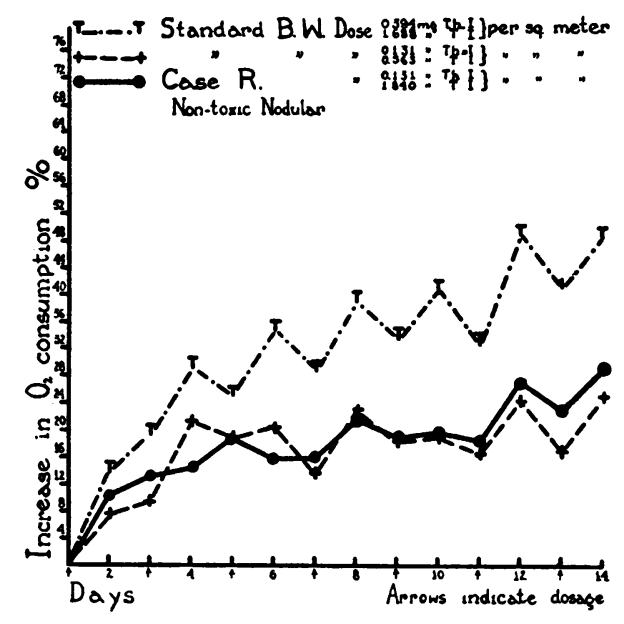

FIg. 6. 


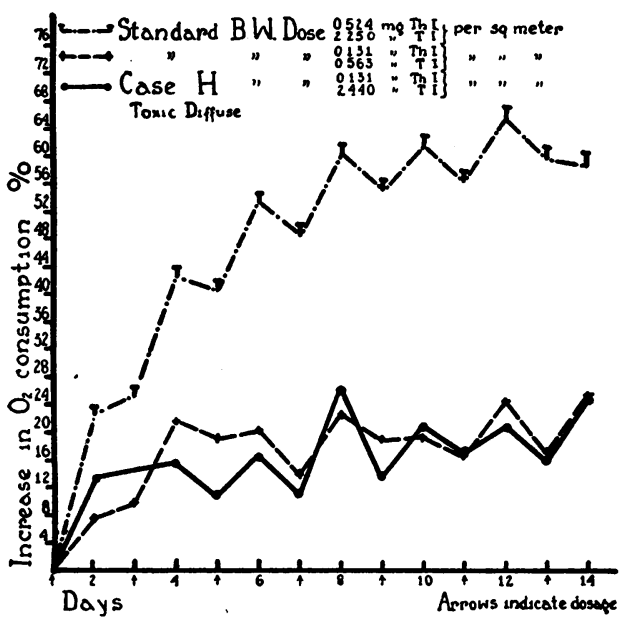

Fig. 7.

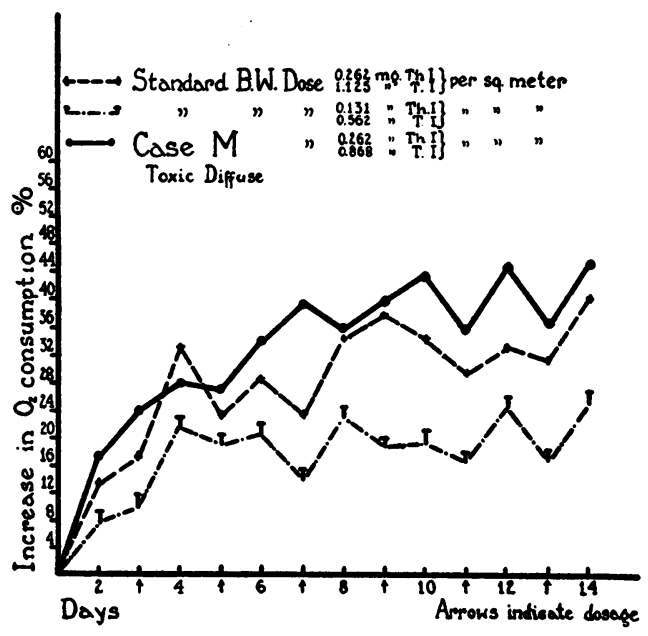

Fic. 9.

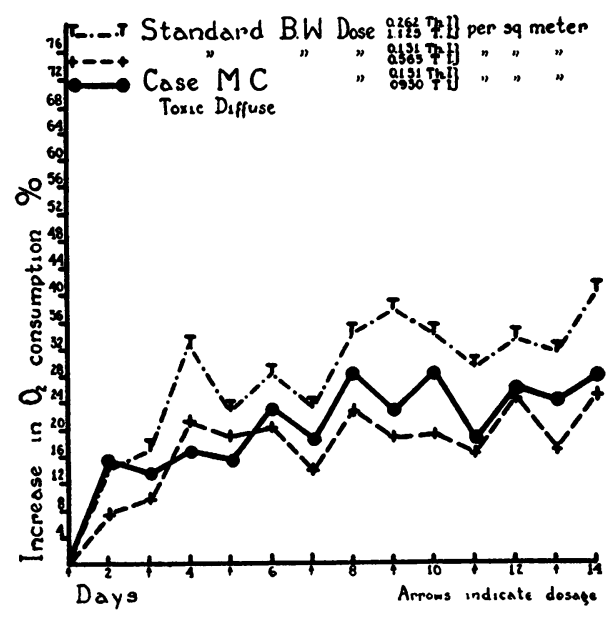

Fig. 11.

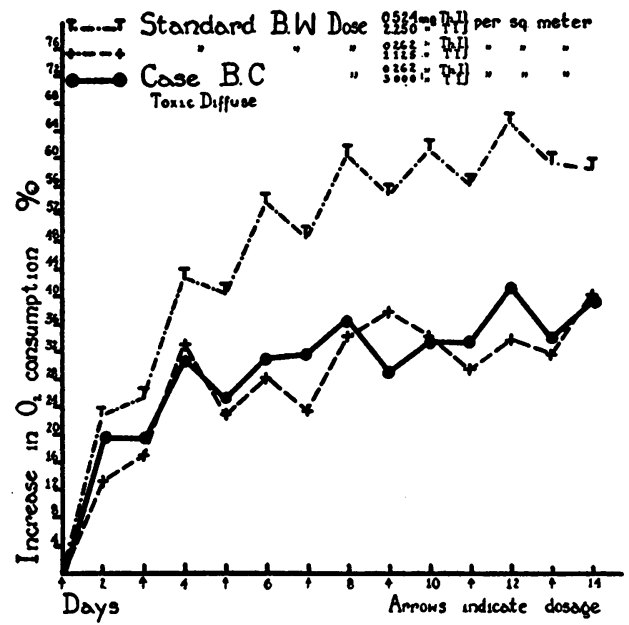

Fig. 8.

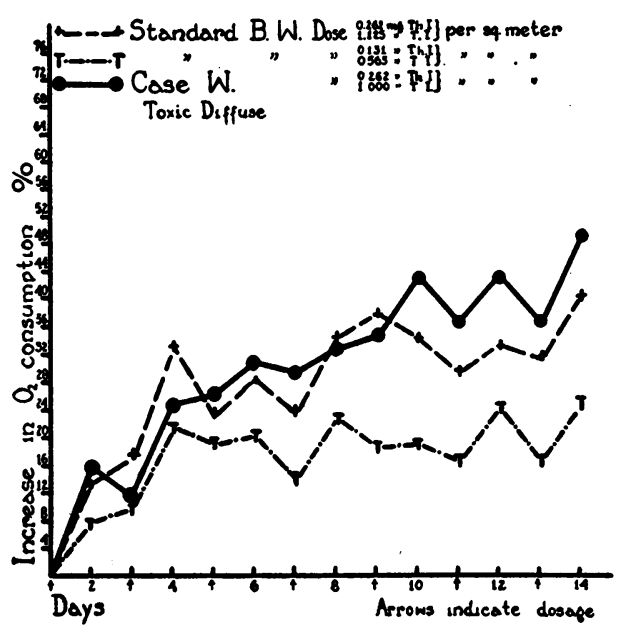

Frg. 10.

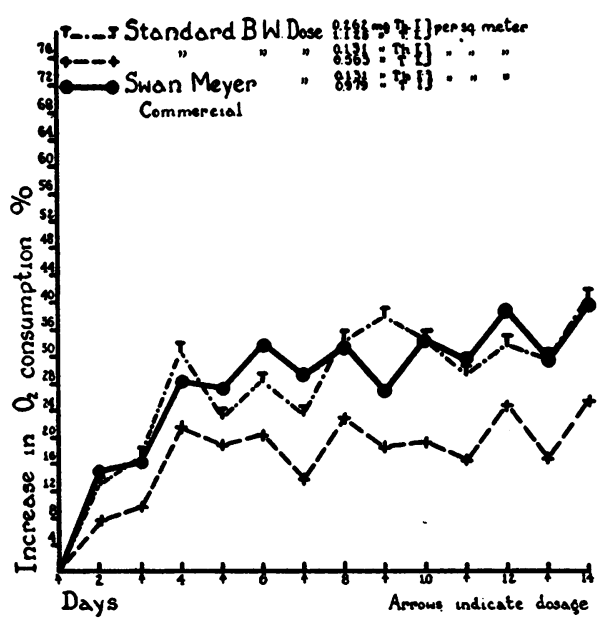

FIG. 12. 


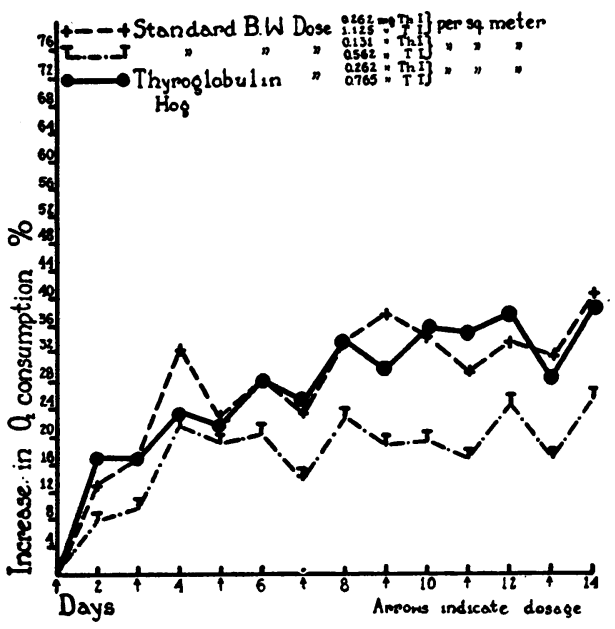

Fig. 13.

Figs. 3 to 13, Inclusive. Comparisons Between Increases in Oxygen Consumption Produced by the Standard Thyroid Preparation, Burroughs Wellcome Company, and Human Thyroid Gland Preparations.

Broken line (---) represents the increase in oxygen consumption observed after administration of an amount of the standard thyroid preparation containing the same dosage of thyroxine iodine as of the unknown preparation (-) given. Broken line (-.-.) represents the increase in oxygen consumption of the standard after administration of a dose containing an amount of total iodine approximately equivalent to that in the unknown preparation. Standard curves are taken from Figure 1. Points are obtained by averaging the increase in oxygen consumption of all of the animals of a group.

TABLE III

Effects of administration of desiccated thyroid, thyroglobulin and thyroxine to guinea pigs

\begin{tabular}{|c|c|c|c|c|c|c|}
\hline \multirow{2}{*}{ Preparation } & \multirow{2}{*}{$\begin{array}{c}\text { Animal } \\
\text { number }\end{array}$} & \multicolumn{2}{|c|}{$\begin{array}{l}\text { Increase in } \mathrm{O}_{2} \\
\text { consumption }\end{array}$} & \multicolumn{2}{|c|}{$\begin{array}{l}\text { Mean increase in } \mathrm{O}_{2} \text { consumption } \\
\text { resulting from administration of } \\
\text { standard, Burroughs Wellcome }\end{array}$} & \multirow{2}{*}{$\begin{array}{l}\text { Average weight loss } \\
\text { on } 14 \text { th day with } \\
\text { unknown prepara- } \\
\text { tions }\end{array}$} \\
\hline & & $\begin{array}{l}\text { Mean of last } \\
3 \text { days of indi- } \\
\text { vidual animals }\end{array}$ & $\begin{array}{c}\text { Mean of } \\
\text { group }\end{array}$ & $\begin{array}{c}\text { In equithyroxine } \\
\text { I dosage }\end{array}$ & $\begin{array}{l}\text { In equitotal } \\
\text { iodine dosage* }\end{array}$ & \\
\hline Case 9. Normal. ................ & $\begin{array}{l}70 \\
73 \\
74 \\
75 \\
76 \\
77 \\
78\end{array}$ & $\begin{array}{c}\text { per cent } \\
30.7 \\
48.3 \\
34.9 \\
34.6 \\
27.9 \\
21.2 \\
23.0\end{array}$ & per cent & per cent & per cent & $\begin{array}{c}\text { per cent of average } \\
\text { initial body weight } \\
8.0\end{array}$ \\
\hline Case 11. Normal.............. & $\begin{array}{l}63 \\
65 \\
66 \\
67 \\
68 \\
69\end{array}$ & $\begin{array}{l}39.7 \\
43.7 \\
36.6 \\
31.8 \\
34.2 \\
31.8\end{array}$ & 36.3 & 35.3 & 29.0 & 9.5 \\
\hline Swan-Meyer.t Commercial......... & $\begin{array}{l}112 \\
113 \\
114 \\
115 \\
116 \\
117\end{array}$ & $\begin{array}{l}31.9 \\
33.6 \\
38.3 \\
40.7 \\
40.6 \\
34.3\end{array}$ & 36.6 & 22.2 & 33.0 & 12.7 \\
\hline
\end{tabular}

* Each figure represents the increase in $\mathrm{O}_{2}$ consumption which would be expected to result from a dose of Burroughs Wellcome, standard, containing the same amount of total iodine as the dose of the unknown preparation given. Figures are interpolated from the standard curve (Figure 2).

$t$ Experiment was repeated with a second group of animals-similar results were obtained. 
TABLE III-Continued

\begin{tabular}{|c|c|c|c|c|c|c|}
\hline \multirow{2}{*}{ Preparation } & \multirow{2}{*}{$\underset{\text { number }}{\text { Animal }}$} & \multicolumn{2}{|c|}{$\begin{array}{l}\text { Increase in } \mathrm{O}_{2} \\
\text { consumption }\end{array}$} & \multicolumn{2}{|c|}{$\begin{array}{l}\text { Mean increase in } \mathrm{O}_{2} \text { consumption } \\
\text { resulting from administration of } \\
\text { standard. Burroughs Wellcome }\end{array}$} & \multirow{2}{*}{$\begin{array}{c}\text { Average weight loss } \\
\text { on 14th day with } \\
\text { unknown prepara- } \\
\text { tions }\end{array}$} \\
\hline & & $\begin{array}{r}\text { Mean of last } \\
3 \text { days of indi- } \\
\text { vidual animals } \\
\end{array}$ & $\begin{array}{c}\text { Mean of } \\
\text { group }\end{array}$ & $\begin{array}{c}\text { In equithyroxine } \\
\text { I dosage }\end{array}$ & $\begin{array}{c}\text { In equitotal } \\
\text { iodine dosage* }\end{array}$ & \\
\hline Case $P$. Non-toxic nodular goiter...... & $\begin{array}{l}29 \\
30 \\
32 \\
33 \\
34 \\
35\end{array}$ & $\begin{array}{c}\text { per cent } \\
22.1 \\
20.0 \\
23.6 \\
22.3 \\
25.9 \\
17.9\end{array}$ & $\begin{array}{l}\text { per cent } \\
22.0\end{array}$ & $\begin{array}{l}\text { per cent } \\
22.2\end{array}$ & $\begin{array}{l}\text { per cent } \\
47.0\end{array}$ & $\begin{array}{c}\text { per cent of averege } \\
\text { initial body weight } \\
7.2\end{array}$ \\
\hline Case $R . \quad$ Non-toxic nodular........... & $\begin{array}{l}38 \\
44 \\
46 \\
47 \\
48 \\
49\end{array}$ & $\begin{array}{l}23.1 \\
38.4 \\
18.3 \\
24.6 \\
24.2 \\
30.0\end{array}$ & 26.4 & 22.2 & 53.0 & 4.4 \\
\hline Case $H . \quad$ Toxic diffuse goiter......... & $\begin{array}{l}72 \\
80 \\
81 \\
82 \\
83 \\
84\end{array}$ & $\begin{array}{l}22.7 \\
17.4 \\
21.4 \\
20.8 \\
22.5 \\
16.1\end{array}$ & 20.2 & 22.2 & 65.0 & 2.4 \\
\hline Case B.C. Toxic diffuse goiter........ & $\begin{array}{l}85 \\
86 \\
87 \\
88 \\
89 \\
90\end{array}$ & $\begin{array}{l}34.7 \\
39.8 \\
41.7 \\
36.5 \\
40.7 \\
36.2\end{array}$ & 38.3 & 35.3 & $65.0+$ & 5.9 \\
\hline Case W. Toxic diffuse goiter. ........ & $\begin{array}{l}91 \\
94 \\
95 \\
96 \\
97 \\
98\end{array}$ & $\begin{array}{l}27.9 \\
44.1 \\
42.7 \\
62.4 \\
36.7 \\
46.1\end{array}$ & 43.3 & 35.3 & 33.0 & 8.7 \\
\hline Case M. $\dagger$ Toxic diffuse goiter....... & $\begin{array}{l}100 \\
101 \\
103 \\
104 \\
105\end{array}$ & $\begin{array}{l}37.9 \\
57.4 \\
42.0 \\
45.2 \\
28.2\end{array}$ & 42.1 & 35.3 & 30.0 & 12.5 \\
\hline Case M. C.† Toxic diffuse goiter...... & $\begin{array}{l}106 \\
107 \\
108 \\
109 \\
110 \\
111\end{array}$ & $\begin{array}{l}29.9 \\
28.1 \\
25.0 \\
30.4 \\
30.4 \\
12.9\end{array}$ & 26.1 & 22.2 & 31.0 & 8.2 \\
\hline Pure thyroxine as di-sodium salt by mouth & $\begin{array}{l}16 \\
18 \\
19 \\
20 \\
21 \\
22\end{array}$ & $\begin{array}{r}23.2 \\
8.6 \\
21.3 \\
21.1 \\
14.8 \\
18.4\end{array}$ & $\begin{array}{c}\text { After } \\
14 \text { days } \\
17.9\end{array}$ & 35.3 & & 0.0 \\
\hline Thyroglobulin. Hog $\ldots \ldots \ldots \ldots \ldots$ & $\begin{array}{l}118 \\
119 \\
120 \\
122 \\
123\end{array}$ & $\begin{array}{l}28.8 \\
49.3 \\
36.7 \\
25.0 \\
34.0\end{array}$ & 34.8 & 35.3 & 27.0 & 11.8 \\
\hline
\end{tabular}


thyroxine iodine. If, however, the calorigenic effect were proportional to the total iodine, the increase in oxygen consumption would approximate an equi-total iodine dosage of the standard. As will be seen from a study of these curves, with the exception of one case, a satisfactory correlation was observed between the calorigenic effect and the thyroxine iodine content of the series of preparations.

The glands from Cases 9 and 11 (Figures 3 and 4) are human thyroids removed from apparently normal individuals who had met with sudden traumatic death. Histological examination showed the tissue to be normal. The curve of Case 9 follows closely the thyroxine iodine equivalent curve of the standard, and the results of this experiment, therefore, are strikingly in favor of the thyroxine iodine as a measure of the calorigenic activity of the preparation. On the basis of the total iodine content of the dose administered (2.3 mgm.) an increase in the oxygen consumption of more than 61 per cent (average of the last 3 days) would have been expected. An average increase of 31.5 per cent was obtained, which agrees with the thyroxine iodine equivalent of the standard 35.3 per cent sufficiently well for this type of work. A better agreement, 36.3 per cent, was obtained with Case 11 (Figure 4), although the results as a whole are not as striking since the total iodine content did not differ as widely from the standard. If the activity were proportional to the total iodine the curve should fall in this case between the two standard curves shown.

Figures 5 and 6 (Cases $P$ and $R$ ) show results obtained with two non-toxic nodular glands. There can be no doubt in either of these cases that the activity parallels the thyroxine fraction of the total iodine.

The calorigenic effect of the preparations from cases of toxic diffuse goiter, H, B.C., M, W and M.C., are shown in Figures 7, 8, 9, 10 and 11 respectively. In the two preparations from toxic diffuse glands, Cases $\mathrm{H}$ and B.C., plotted in Figures 7 and 8, the increase in oxygen consumption is in striking agreement with the standard based on equi-thyroxine dosage, notwithstanding the large non-thyroxine iodine moiety in these two glands. The preparations from Cases $M, W$, and M.C., also toxic glands, recorded in Figures 9, 10 and 11 , caused a slightly greater increase in oxygen consumption than might be expected when compared with the standard. In each of the two animal groups to which preparations from Cases $M$ and $W$ were administered there was a hypersensitive animal which raised the average (see Table III). Discrepancies of this type are to be expected with the method employed.

The commercial thyroid preparation of SwanMeyer is included in the series (Figure 12). The increase in oxygen consumption observed when this preparation was given to six guinea pigs is higher than would be expected on the basis of its thyroxine content as determined by chemical analysis. Since this was the only preparation which proved to be inconsistent with the thyroxineoxygen consumption relationship the experiment was repeated and the same result was obtained. While the unbroken line of Figure 12 should fall on the lowest standard curve in order to regard the activity as parallel to the thyroxine content, it actually falls above the theoretical total iodine curve. It is possible that some "filler" was present in this commercial preparation which interfered with the correct determination of thyroxine. An effort was made to obtain more material for further chemical investigation but unfortunately the company had ceased to make the product.

A comparison was made between the standard and a thyroglobulin preparation kindly supplied by Dr. M. Heidelberger. This material had not been submitted to any process of drying. The increase in oxygen consumption observed (Figure 13) was practically identical with the equi-thyroxine dose of the standard. From this it was concluded that the process of drying employed for our desiccated thyroid material had not decreased the biological activity.

A summary of the results of this investigation is shown in Figure 14. When the increase in oxygen consumption is plotted against the total iodine content of the dose of thyroid administered, the results show a marked scatter. However, when plotted against thyroxine content, the results (with the exception of one mentioned above) are found to group themselves closely about the points representing equivalent amounts of thyroxine iodine in the standard. From these 


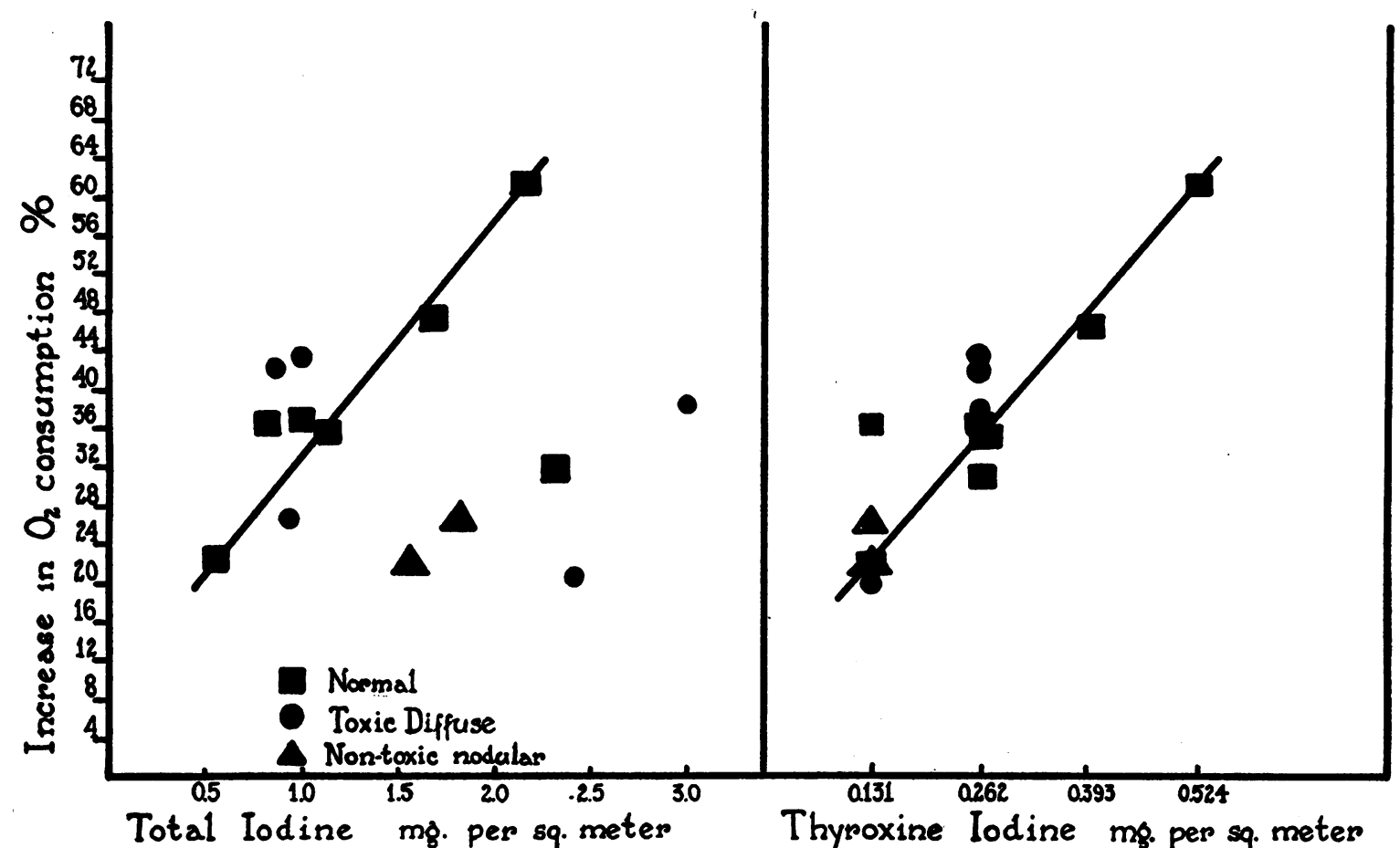

Calorigenic Effect of Normal and Pathological Thyroid Gland Preparations When AdminISTERED IN EQUI-IODINE DOSES.

Calorigenic Effect of Normal and Pathological Thyroid Gland Preparations When AdMinistered in EQui-THYroxine Iodine Doses.

FIg. 14.

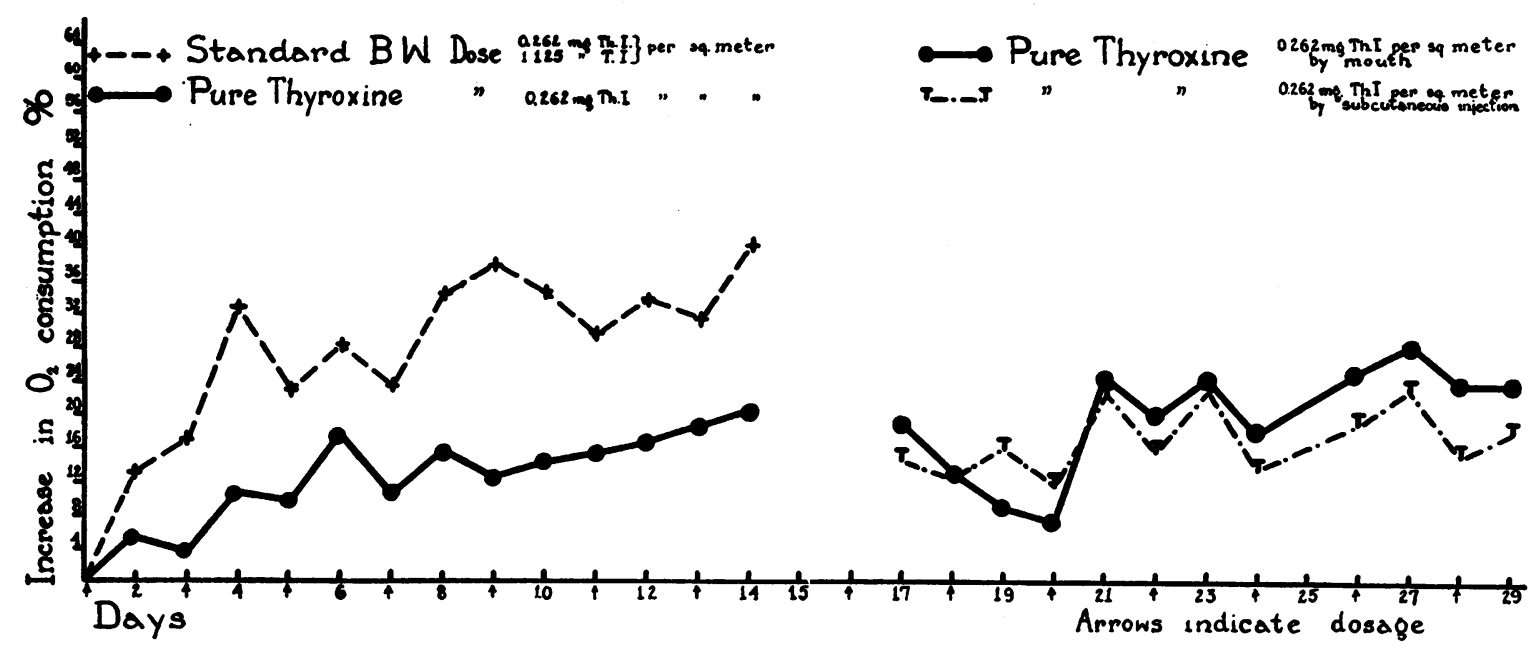

Fig. 15. Comparison Between Increases in Oxygen Consumption Produced by Standard, Burroughs Wellcome Company Thyroid, and the Di-sodium Salt of Racemic Thyroxine When Administered in EQUI-THYROXINE IODINE Doses. 
results it seems reasonable to conclude that the calorigenic activity of desiccated thyroid preparations is proportional to the thyroxine iodine content as determined chemically rather than to the total iodine content of the gland.

A comparison (Figure 15) was made between the standard and pure crystalline thyroxine ${ }^{1}$ in alkaline solution. After 14 days of dosage a mean increase of only 17.5 per cent in the oxygen consumption was observed as compared with 35.3 per cent obtained with an equi-thyroxine dose of the standard. To eliminate the possibility of failure of absorption, two of the six animals of the group were chosen as controls and were given the same dose by mouth over a second 14 day period while the remaining four were injected subcutaneously. At the end of the second 14 day period (total of 28 days) the two animals receiving the dose by mouth showed an increase in oxygen consumption of from 17.5 to 25 per cent, while those who had been injected had only increased from 17.5 to 18.5 per cent. In other words, the dose when given by mouth had been as effective as when administered parenterally, therefore the fact that only 50 per cent as much effect was obtained as in the case of the standard could not be attributed to lack of absorption.

\section{DISCUSSION}

An analysis of the data presented above permits of a reasonably definite answer to the first question proposed. With one exception, normal and pathological thyroid preparations when administered to normal guinea pigs increased the oxygen consumption in proportion to the amount of thyroxine contained therein. No correlation between the total iodine of the glands and increase in metabolic rate was observed. The one preparation not consistent with the other eleven does not, it is believed, invalidate the conclusion reached. As mentioned above the preparation was a commercial product, and the possibility of error in the chemical determination of thyroxine could not be ruled out on account of lack of material.

1 Thyroxine was isolated from Burroughs Wellcome Company thyroid by extraction of alkaline hydrolysate with butyl alcohol. The iodine content of this preparation was 63.1 per cent as determined by Pregl's method. Calculated 65.4 per cent.
The experiments bring forward no evidence for or against the postulate of " active iodine" not in the form of thyroxine. It is possible that there may exist within thyroid glands, both normal and pathological, so called " active iodine" not in the form of thyroxine but, if this be so, such iodine would appear, from the results obtained, to exist in amounts proportional to the amount of thyroxine present.

Because of the length of time required for a single experiment, the preparations selected for study are not large in number. They include, however, a sufficiently wide range of the normal and pathological human glands to bring out differences should such exist. The non-iodized toxic diffuse gland is, unfortunately, not included in the series. As much as this type of gland is desired, it was not considered right or proper to request a surgeon to operate on a toxic patient without previous administration of iodine. Whether the same relationship between the thyroxine content of the non-iodized toxic glands and oxygen consumption pertains as in iodized glands is not known.

Is there an abnormal (17) substance more toxic than the normal hormone present in the toxic goiter, particularly the toxic diffuse gland? From the evidence available the question may be answered in the negative. Certainly, so far as the calorigenic activity of the glands is concerned, there is no difference to be observed between normal, non-toxic and toxic glands. Particular attention to toxic symptoms during the administration of preparations from toxic glands revealed no differences in toxic and non-toxic glands. Evidence against the presence of an abnormal toxic substance in the toxic diffuse goiters would be more conclusive were it possible to report observations on a non-iodized toxic gland.

The method selected for the biological assay of the thyroid gland preparations appeared to be the most suitable in the circumstances. On account of the well known variability among clinical conditions it was considered highly desirable to use separate individual glands and not to employ combinations. Small animals were necessary for this reason. Normal instead of thyroidectomized animals were chosen. On theoretical grounds, perhaps, thyroidectomized animals might be preferred. The experience of Gaddum (18), to- 
gether with a preliminary observation in our laboratory, indicates that this is not the case. It is true that human subjects with spontaneous myxedema are more sensitive to the administration of thyroid gland than are normal individuals. Aside from the increased sensitivity of myxedematous patients there is no evidence that the effect of the thyroid hormone is in any way different from normal. In both animals and human subjects, either with hypothyroidism or without, there is considerable variability in response to the administration of thyroid gland. In the experimental work, the attempt has been made to compensate for this variation by including at least six animals for a given preparation, and calculating the increase in oxygen consumption from the normal of each animal rather than the group normal average.

The discrepancy between the calorigenic activity observed with crystalline racemic thyroxine administered as the di-sodium salt may be accounted for in large part by the relatively low activity of the racemic compound as compared with 1-thyroxine, the form in which the hormone probably exists in the gland (19). Gaddum (18) has found the 1 -form to be three times as active as the d-form, which indicates that an equi-thyroxine iodine dose of the dried thyroid standard should show 1.5 times as much activity as racemic thyroxine. Activity two times as great was actually found, a result that only approximates the expected value. In this connection, it should be mentioned that Salter, Lerman and Means (20) found no difference in the calorigenic activity of the $d-$ and 1 -forms of thyroxine when administered to patients with spontaneous myxedema.

The results tabulated in Table III are in general agreement with those found by Gaddum and Hetherington (9), Rotter and Mecz (10), and Sjögren and Lundgren (11) when different biological methods were used. The discrepancy between the conclusions drawn from this investigation and those of Hunt and Seidell (1) and of Krogh and Lindberg (2) may be apparent rather than real. As the preparations used by these workers were not analyzed for their thyroxine iodine content the possibility exists that the thyroxine per cents of total iodine may have been so nearly alike that activity proportional to total iodine might also be proportional to thyroxine iodine. The results of this study are at variance with the work of Means, Lerman and Salter (3) (21). The method of biological assay used in our studies is different from that employed by these investigators and may account for the difference in results obtained.

\section{SUMMARY}

1. The calorigenic effects on normal guinea pigs of twelve preparations of thyroid glands in equi-thyroxine doses have been studied. These preparations consisted of two commercial thyroid gland products, one preparation of hog thyroglobulin, and nine human thyroid glands two of which were normal, two non-toxic and five toxic diffuse.

In addition, the calorigenic effect of racemic thyroxine administered as the di-sodium salt was studied.

2. The results obtained indicate that the calorigenic activity of desiccated thyroid preparations is proportional to the thyroxine content of the gland as determined by the method of Leland and Foster.

3. The calorigenic activity of crystalline racemic thyroxine administered as the di-sodium salt was only 50 per cent as great as an equithyroxine dose of thyroid gland. It is suggested that this reduced effect may be explained by the greater activity of 1-thyroxine, the form in which the hormone exists in whole gland.

4. No evidence was obtained in favor of the existence of an abnormal substance contributing to the toxicity of pathological glands.

\section{BIBLIOGRAPHY}

1. Hunt, R., and Seidell, A., Studies on thyroid. I. The relation of iodine to the physiological activity of thyroid preparations. Bull. 47, Hygienic Laboratory, U. S. Public Health and Marine Hospital Service, October, 1908, Washington Government Printing Office, 1909.

Hunt, R., The acetonitrile test for thyroid and of some alterations of metabolism. Am. J. Physiol., 1923, 63, 257; Standardization of thyroid preparations. Arch. Int. Med., 1925, 35, 671.

2. Krogh, M., and Lindberg, A., Studies on the thyroid gland. II. The physiological activity of iodin in thyroxin and in normal and pathological thyroid glands. Acta path. et microbiol. Scandinav., 1932, 9, 21. 
3. Means, J. H., Lerman, J., and Salter, W. T., The rôle of thyroxine iodine and total organic iodine in the calorigenic action of whole thyroid gland. J. Clin. Invest., 1933, 12, 683.

4. Harington, C. R., and Randall, S. S., The chemical assay of thyroid gland. Quart. J. Pharm. and Pharmacol., 1929, 2, 501.

5. Thompson, W. O., McLellan, L. L., Thompson, Phebe K., and Dickie, Lois F. N., The rates of utilization of thyroxine and of desiccated thyroid in man: The relation between the iodine in desiccated thyroid and in thyroxine. J. Clin. Invest., 1933, 12, 235.

6. Thompson, W. O., Thompson, Phebe K., Taylor, S. G., III, and Dickie, Lois F. N., Calorigenic action of single large doses of desiccated hog thyroid: Comparison with the action of thyroxine given orally and intravenously. Arch. Int. Med., 1934, 54, 888.

Thompson, W. O., Thompson, Phebe K., Taylor, S. G., III, Nadler, S. B., and Dickie, Lois F. N., The pharmacology of the thyroid in man. J. A. M. A., 1935, 104, 972.

7. Mфrch, J. R., Standardization of thyroid preparations. J. Physiol., 1929, 67, 221.

8. Kreitmair, H., Jodgehalt und Schilddrüsenwirkung. Zugleich, Ztschr. ges. exper. Med., 1928, 61, 202.

9. Gaddum, J. H., and Hetherington, M., The activity of thyroid preparations given by mouth to mice. Quart. J. Pharm., 1931, 4, 183.

10. Rotter, G., and Mecz, M., Zur Standardisierung von Thyreoideapräparaten. Arch. f. exper. Path. u. Pharmakol., 1932, 166, 649.

11. Sjögren, B., and Lundgren, R., Om värdesättandet av handelns thyreoideapreparat. Svensk Farm. Tid., 1933, 37, 261 and 281.
12. Freud, P., and Nobel, E., Auswertung des Thyreoidins am Meerschweinchen. Klin. Wchnschr., 1924, 3, 1849.

13. Foster, G. L., and Gutman, A. B., On the fate of diiodotyrosine in the animal organism. J. Biol. Chem., 1930, 87, 289.

14. Leland, J. P., and Foster, G. L., A method for the determination of thyroxine in the thyroid. J. Biol. Chem., 1932; 95, 165.

15. Palmer, W. W., and Leland, J. P., Observations on M $\phi$ rch's method for standardization of thyroid gland preparations. Proc. Soc. Exper. Biol. and Med., 1932, 29, 1195.

16. Foster, G. L., and Sundstroem, E. S., A respiration apparatus for small animals. J. Biol. Chem., 1926, 69, 565.

17. Plummer, H. S., Results of administering iodin to patients having exophthalmic goiter. J. A. M. A., 1923, 80, 1955.

The function of the thyroid gland. Beaumont Foundation Lectures, Series No. 4, St. Louis, 1926.

18. Gaddum, J. H., Quantitative observations on thyroxine and allied substances. II. Effects on the oxygen consumption of rats. J. Physiol., 1929-30, 68, 383.

19. Harington, C. R., and Salter, W. T., The isolation of 1-thyroxine from the thyroid gland by the action of proteolytic enzymes. Biochem. J., 1930, 24, 456.

20. Salter, W. T., Lerman, J., and Means, J. H., The calorigenic action of $\mathrm{d}$ - and 1-thyroxin. J. Clin. Invest., 1935, 14, 37.

21. Lerman, J., and Salter, W. T., The calorigenic action of thyroid and some of its active constituents. Endocrinology, 1934, 18, 317. 